\title{
Supporting women farmers in the green zones of Mozambique
}

Ruth Ansah Ayisi

Follow this and additional works at: https://knowledgecommons.popcouncil.org/departments_sbsr-pgy

Part of the Agricultural and Resource Economics Commons, Family, Life Course, and Society

Commons, Gender and Sexuality Commons, Inequality and Stratification Commons, and the International

Public Health Commons

How does access to this work benefit you? Let us know!

\section{Recommended Citation}

Ayisi, Ruth Ansah. 1995. "Supporting women farmers in the green zones of Mozambique," SEEDS no. 17. New York: Population Council. 
and

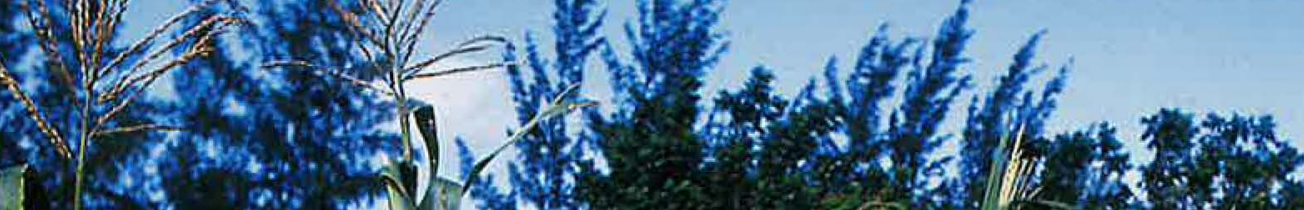

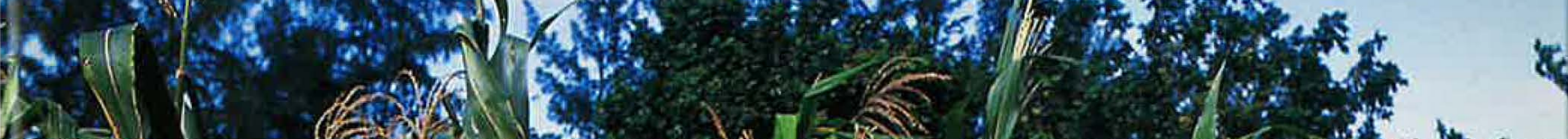

Lisiven

(a) 1 .

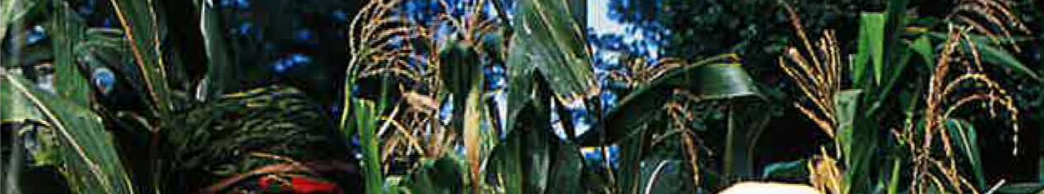

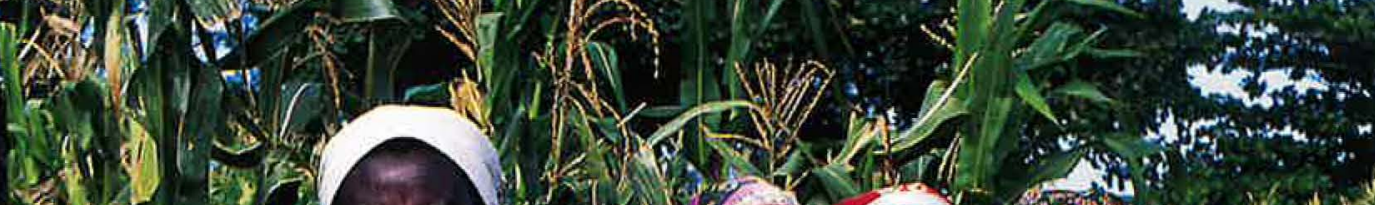
(1) W.

I
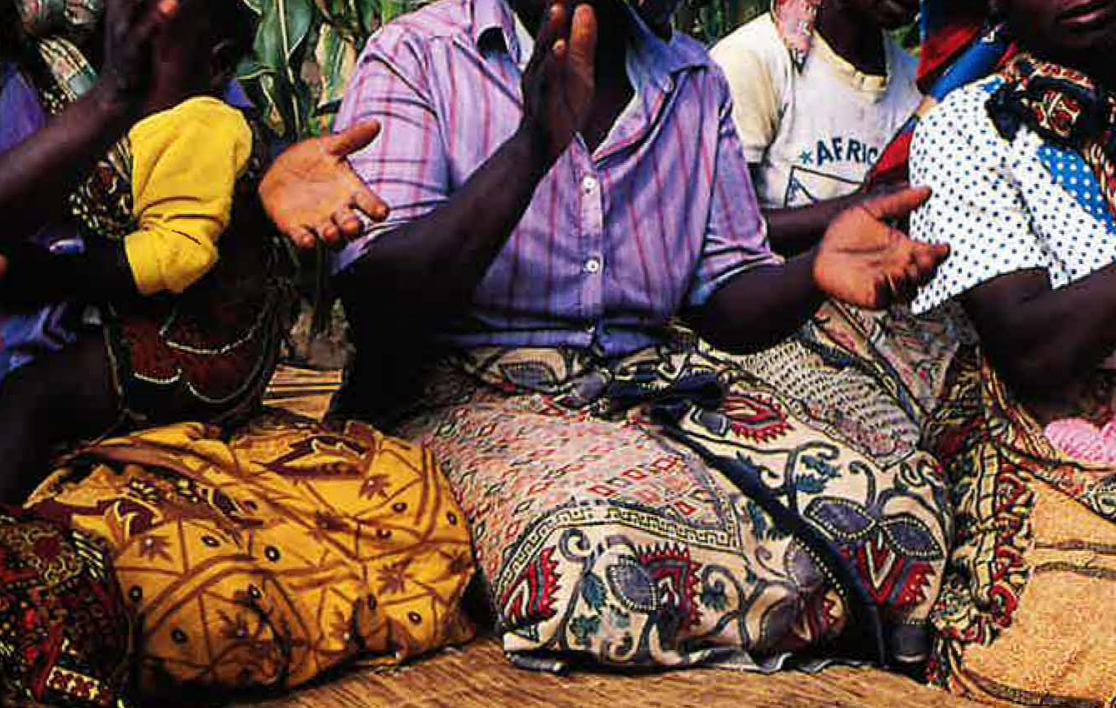

ints
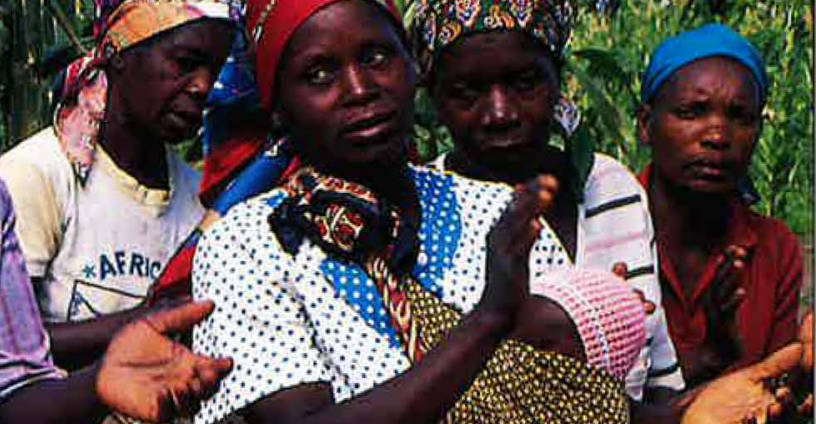
SEEDS is a pamphlet series developed to meet requests from all over the world for information about innovative and practical program ideas developed to address the economic roles and needs of low income women. The pamphlets are designed as a means to share information and spark new initiatives based on the positive experiences of projects that are working to help women generate livelihoods and to improve their economic status. The projects described in this and other issues of SEEDS have been selected because they have served not only to strengthen women's productive roles, but also to integrate women into various sectors of development, both social and economic. All projects documented in the SEEDS series involve women in decision-making, organize women locally, and address broader policy issues which affect the economic roles of women.

These reports are not meant to be prescriptive, since every development effort will face somewhat different problems and possibilities. Rather, they have been written to describe the history of an idea and its implementation in the hope that the lessons learned can be useful in a variety of settings. They are also being written to bring to the attention of those in decision-making positions the vital roles that women play not only in the economies of their individual households but also in the economic life of every nation.

No. 171995

ISSN 073-6833

Copyright (1995 SEEDS
The Population Council provides project direction and administrative support for SEEDS. Editorial policy is set by the SEEDS Steering Commiltee: Judith Bruce (Population Council), Betsy Campbell (The Ford Foundation), Marilyn Carr (UNIFEM), Marty Chen (Harvard Institute for Internalional Development), Margaret Clark (The Aspen Instilule), Misrak Elias (UNICEF), Anne Kubisch (The Aspen Instilute), Ann Leonard (The Population Council), Cecilia Lotse (UNICEF), Katharine McKee (Communily Development Financial Institutions Fund), Kirsten Moore (Population Council), Anne Walker (International Women's Tribune Center), and Mildred Warner (Cornell University).

This edition of SEEDS has been developed in cooperation with the United Nations Children's Fund (UNICEF) Development Programme for Women in New York and the UNICEF country office in Maputo, Mozambique. Publicalion of SEEDS is made possible by support of the Ford Foundation, UNICEF, and the Population Council.

Stalements made and views expressed in this publication are solely the responsibility of the authors and nol of any organization providing support for SEEDS, 


\title{
Supporting Women Farmers in the Green Zones of Mozambique
}

\author{
by Ruth Ansah Ayisi
}

\section{Introduction}

Women throughout much of the developing world are farmers, not only producing the food crops needed to feed their families, but seeking to generate the cash income necessary to gain access to education, health care, and a better way of life in today's world. However, in many countries-particularly in subSaharan Africa-women farmers must deal not only with the inherent difficulties of gender inequities, poverty, and the vagaries of nature, but with the consequences of war and civil strife as well. This case study focuses on efforts that are helping women farmers to survive and prosper in the Green Zones of Mozambique - and to provide desperately needed foodstuffs for the local market-despite years of brutal warfare in what is currently one of the poorest countries in the world.

This case study is the result of a collaboration with UNICEF/Mozambique and UNICEF's Development Programme for Women in New York. 


\section{Background}

For the first time in over a decade and a half, Mozambicans are enjoying peace-a peace that was a long time coming.

For over 500 years, Mozambique (a nation of 16 million people situated on Africa's southeastern coast and bordering on Malawi, Zimbabwe, and South Africa) suffered under Portuguese colonial rule. This was a time of virtual slave labor, when Mozambicans were forced to neglect their own food crops to grow cash crops for export, primarily to neighboring Rhodesia and South Africa. Then, in 1975, after ten years of armed struggle, Mozambique gained its independence. The Portuguese finally departed, but they left bitterly, taking with them all their belongings and destroying much of what they could not carry off. The economy was in shambles and social services were all but nonexistent. At independence, less than 10 percent of the population had received any formal education and over 90 percent could not read or write. Adequate health care could only be found in the capital, Maputo, and potable water was only available in or around urban areas where only about 30 percent of the population reside.

Worse still, the euphoria that accompanied independence proved to be short-lived. Fighting soon recommenced between the new Government of the Mozambique Liberation Front (FRELIMO) and rebels of the Mozambique National Resistance (RENAMO). Sixteen years of civil strife were to follow, resulting in the killing of hundreds of thousands of people, including many women and children. The country's already precarious economy was further crippled, reducing Mozambique to one of the world's poorest nations.

Estimates of the conflict's costs, in the 1980 s alone, go as high as U.S. \$15 billion. The country's infrastructure was devastated, and agriculture-the country's backbonedeclined as people fled to the safety of the urban areas and coastal districts. Some 1.7 million Mozambicans crossed into neighboring countries while another four million were displaced. In the countryside, women and children were the main victims of atrocities, and hundreds of thousands of people were cut off from the basic means of survival. It is estimated that almost one million people were killed during the war and that over 500,000 children were torn from their families.

Then, as if the war were not enough, in the early 1990s, Mozambique experienced its worst drought in seventy years. As there were huge food shortages, even more people left the fertile lands that still remained under cultivation. Fortunately, the drought did not result in mass famine, because drought is no stranger to Mozambique and the people have developed survival strategies. Many managed to flee to areas where food aid was being distributed, or they survived by eating unusual foods, like wild roots.

The coming of the rains coincided, in 1992, with the signing of a general cease fire between the government and RENAMO. Slowly, those who had fled to neighboring countries or had been internally displaced began to return to their homes. Now the government, RENAMO, aid agencies, and communities themselves have begun the massive task of repairing roads and rebuilding the bridges, wells, schools, and health centers that were destroyed. And agriculture is slowly being revitalized as previously unsecured areas and roads are opening up.

Conflict, drought and, in a different way, peace, have all combined to put Mozambique in a chronic emergency situation. Between mid-1992 and the end of 1994, a United Nations force was in place to keep the peace The task was relatively easy given the desire on the part of Mozambicans themselves for peace.

The peace process culminated in the holding of the country's first multi-party election October 27-29, 1994. President Joaquim Chissano and his ruling FRELIMO party were announced the victors on November 19th, receiving 43.3 percent of the 4.95 million votes cast as opposed to 33.7 percent for his rival, Alfonso Dhlakama and the RENAMO party. The elections were hailed as free and fair with almost 90 percent of registered voters turning out at the polls- - a significant feat as many voters had to travel for as long as a whole day just to reach the polling station.

The newly elected Government faces a truly difficult task. Mozambique's debt burden is one of the world's highest and represents four times the country's Gross Domestic Product. Over 80 percent of the population live in absolute poverty, and UNICEF esti- 


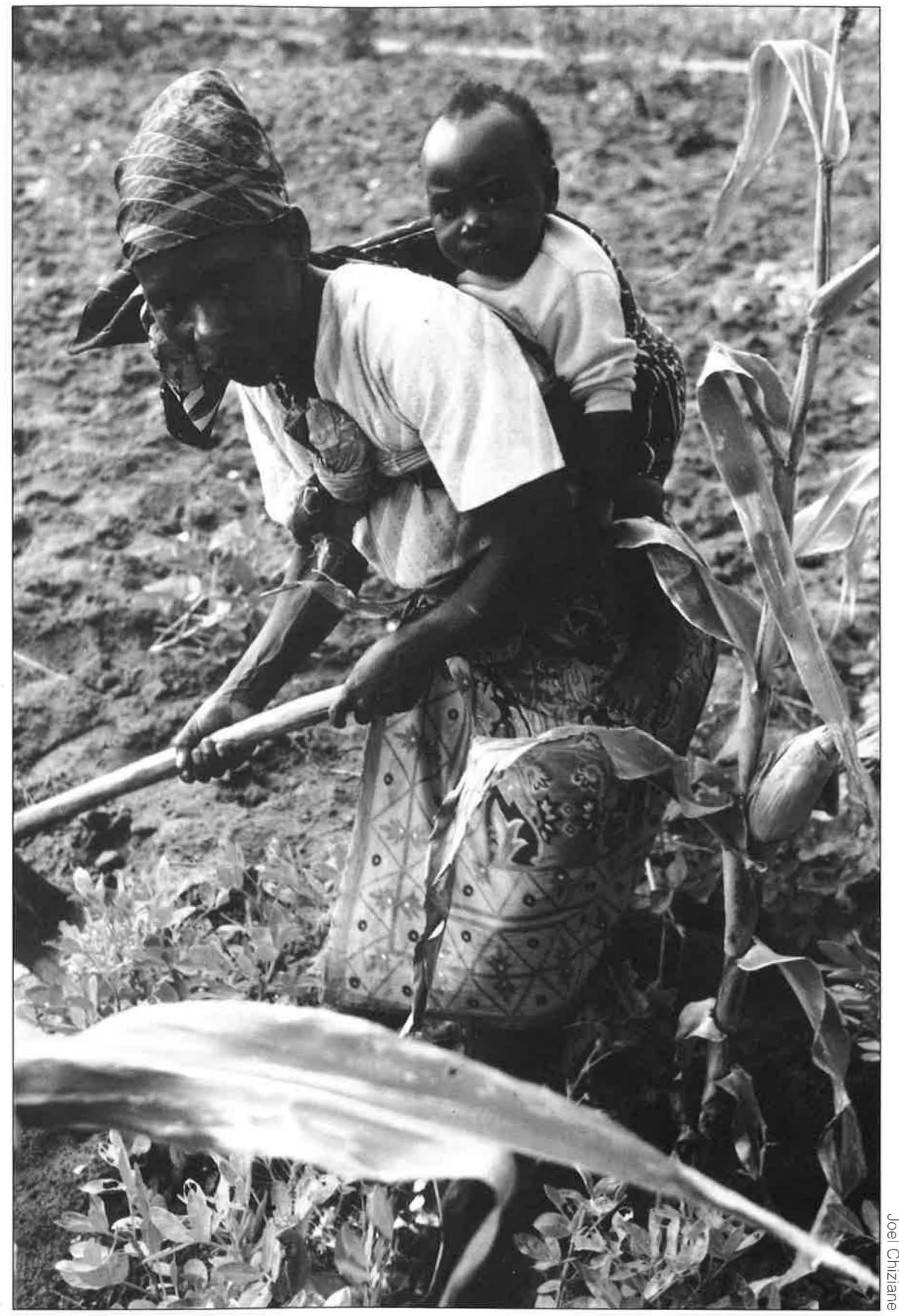


mates that death from disease or lack of food continues to threaten as many as three million, or more than one-third of all children in Mozambique.

While times are hard for everyone, one of the most vulnerable groups in Mozambique is the urban poor who possess little or no land to grow crops. Many urban dwellers are people who once lived off the land, but fled to the safety of the cities during the war. For them, food is no longer something to grow, but something to buy. Prices have risen dramatically since the introduction of the Economic Structural Recovery Program sponsored by the International Monetary Fund and the World Bank in 1987, and unemployment is high. Even for those few who are formally employed, life is tough. Wages have lagged well behind price hikes, and the minimum monthly wage in 1994 is only about U.S. \$13. This makes wages in Mozambique among the lowest in Africa.

\section{The "Green Zones" Initiative}

"Green Zones" is the name frequently given to suburban farm land that surrounds large cities, such as Mozambique's capital, Maputo. Here most of the produce, chicken, eggs, and other foodstuffs found in the urban marketplace are grown. Before independence the Green Zones were primarily underutilized areas not under cultivation. When the Portuguese left, Mozambican farmers moved onto the land and, over the years, many were able to legalize possession through local authorities. However, these farmers knew little about agricultural production techniques.

At about the same time, in an attempt to stimulate agricultural production, the government forced many farmers to work on large, state-run farms. But, these unmanageable "cooperatives" were not highly productive, primarily because the people themselves received few of the benefits and thus were not committed to the movement. They continued to live off their own personal plots, which they farmed after putting in their required hours on the "people's" farms. Not surprisingly, many Mozambicans today are wary of any attempts at collectivization until they can clearly see the benefit of participation.

\section{The Maputo Green Zones Project}

After the failure of the "people's" farms, the government sought other means to increase productivity. In 1980, a Gabinete des Zonas Verdes (Green Zones Cabinet) was established to provide administrative and technical support to both cooperative and private farms within the Green Zones. Administratively attached to the Maputo City Council, the Cabinet was also a part of the Ministry of Agriculture (MOA) and worked through the seven MOA agricultural centers located throughout the Maputo area. These centers were designed to offer technical assistance through the services of extension workers and provision of transport, seeds, fertilizer, and the like.

As in most African countries, women in Mozambique traditionally are responsible for most agricultural work and, therefore, make up the majority of farmers working in the Green Zones. Many of these women are widowed or divorced; others are married to men who have migrated to work in South African mines, making them the essential source of support for their households and families. It was in 1984 that twenty-one Green Zones agricultural cooperatives, operated by about 500 women, were selected to participate in a special project funded by UNICEF. The project would attempt not only to improve agricultural production, but to upgrade the overall standard of well-being of the women and their children.

Operating under the auspices of the Green Zones Cabinet, the project was designed to:

- Increase and improve means of production;

- Provide social infrastructure such as crèches, training centers, and sanitary facilities:

- Offer more training courses in such areas as agriculture, and increase knowledge about basic health, nutrition, and child care; and

- Provide higher compensation for workers in cash or kind.

Immediate goals were to:

- Improve water supply and irrigation systems;

- Establish eleven crèches;

- Provide social infrastructure (stores, latrines, offices, etc.);

- Strengthen training structures and pro- 


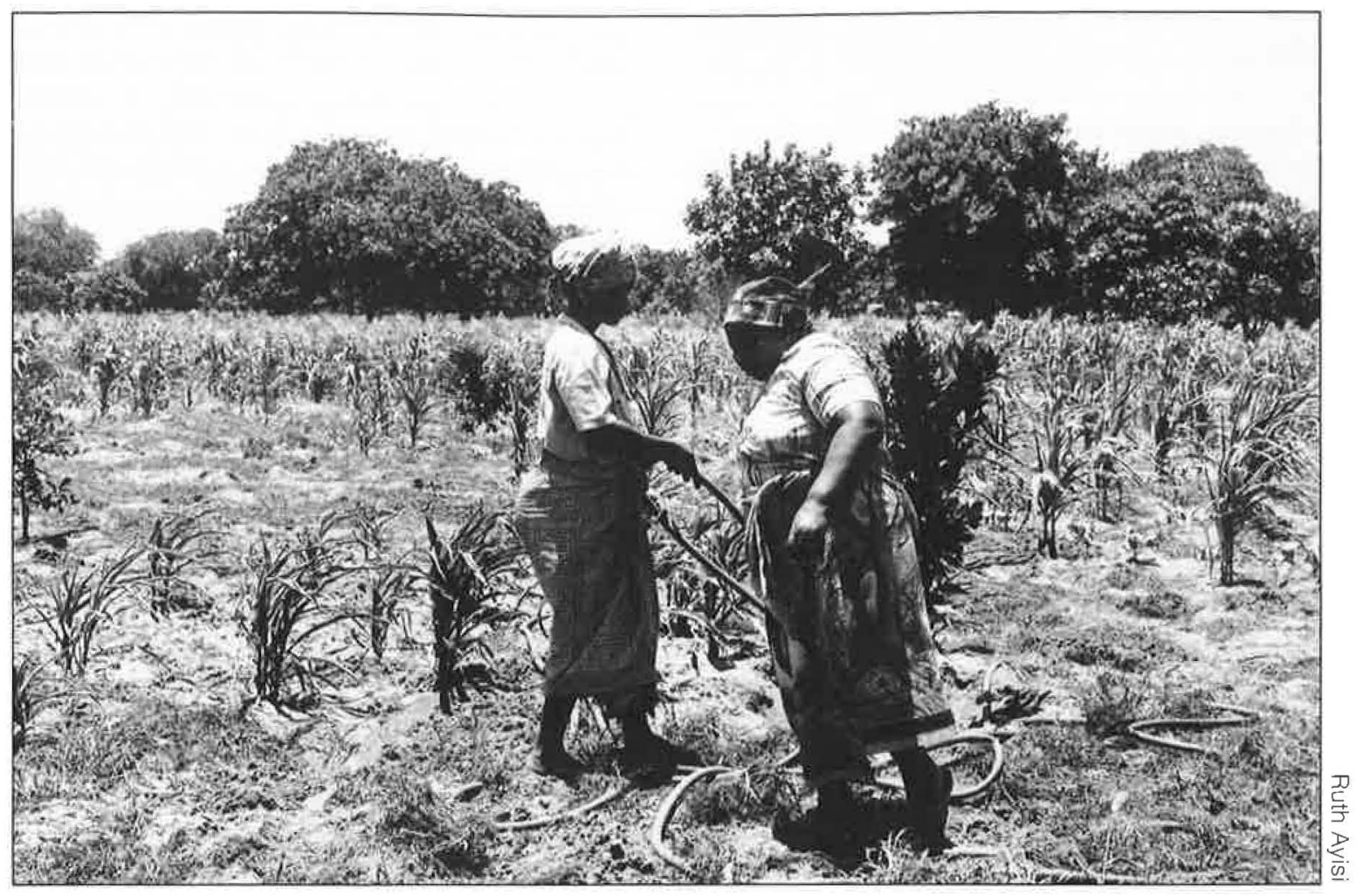

vide didactic materials;

- Increase profitability of co-ops to allow payment of at least minimum wage; and

- Improve the nutritional value of agricultural produce.

The Green Zones area is rich in groundwater, but at the time of the project only a few of the farms were irrigated. Therefore, the sinking of boreholes and provision of pumps were considered of primary importance in boosting production. As few of the cooperatives had any buildings-even sheds-each group was given assistance to construct a storehouse and protected site for cooking.

Because most of the women had no source of child care and few could afford to send their children to school, construction of crèches and literacy centers accessible to each cooperative was also a priority. Minicreches were established within each individual co-op and are run by the co-op members themselves. They are built right in the fields to facilitate breast feeding. And because most of the women themselves were illiterate, classes in basic Portuguese (the national language) were to be provided to all co-op members. To carry out these social programs, nineteen women from the Green Zones were trained by the Ministry of Health as crèche monitors while another group were trained as nutrition monitors. The Ministry of Education trained literacy monitors to conduct two-hour classes daily and supplied the literacy centers with basic equipment.

As malnutrition was still a problem at the time, arrangements were made for the World Food Programme to provide a minimal food basket to each co-op member and her family until the level of production on the farms could be improved. Local dairies supplied milk to the crèches and the government food distributor in Maputo made sure the childcare centers received basic foods such as cereal, oil, sugar, etc.

Through the participation of the People's Development Bank, the cooperatives were able to take out bank loans to cover the cost of constructing buildings and developing other infrastructure. Co-op members also provided the labor needed for construction as well as farming. Thus, the cooperative members were, from the outset, partners in this development effort. 
The co-ops in Matola Gare, about 20 kilometers from the city, are approachable up a sandy track, far from the main road. Plots of neatly cultivated maize lie on either side.

It was the hottest day of the summer during my visit to the Maputo Green Zones. Some women sat on a cane mat under the patchy shade of a fruit tree. They had started in the fields very early in the morning to avoid the full force of the sun. It was now calm with a hot breeze blowing gently. Maputo's city chaos of around two million people seemed far away.

The only constant noise was the clucking of chickens, but they too were quieter than normal. Temperatures had soared to over 40 degrees and many of the chickens were dying. Despite the discomfort, the women (mostly dressed in bright-colored cotton wraps, barefoot, and with scarves on their heads) chatted comfortably.

Christine Malecko, a 45-year-old divorcee, is in charge of the finances of one of six cooperatives that are part of a union named Josina Machel, after the first wife of the late president Samora Machel. Since joining the co-op, her life has improved dramatically. Ms. Malecko now earns 100,000 mt (US $\$ 15$ ) from the cooperative, which is about 25 percent above the minimum wage.

Before joining the cooperative in 1987 , she had lived with her husband. "Then, suddenly, my husband left me after ten years of marriage because I could have no children," said Ms. Malecko, tenderly cradling the baby of another co-op member in her arms. She was talking in the local language, Ronga. "Before he left, my husband built me a house and gave me a plot of land so I could survive on subsistence farming. But it was very difficult. I worked on my machamba (plot of land), but I was growing just enough food to eat. I had to work on the machambas of others to earn money so that I could buy other basics, like soap and clothes.

The hours of labor took their toll. MS. Malecko would start working on other people's plots at 4:00 am, before working on her own plot. Then she had to trek for forty-five minutes to fetch water, and another forty-five minutes to go home with the heavy bucket on her head. "My health wasn't too good, because when your spirits are low it breaks down your health.
In the early 1980s, on hearing that a cooperative had formed in her area, Ms. Malecko jumped at the opportunity. "I thought it was better to join with others than to work by myself." Besides the chickens, she works with other women growing cabbage, carrots, tomatoes, onions, maize, and beans. "We all work well together," she reports. But she still keeps her own machamba, where she grows cashews to sell.

The co-op also gave Ms. Malecko the opportunity to attend literacy classes. She had only completed the first grade at primary school because she had to leave, following the death of her parents, without learning how to read or write. The classes, however, are difficult for most of the women, who not only have to master literacy skills but also have to learn what is for most a new language, Portuguese. Although Ms. Malecko is still unable to read the daily newspaper, she can now sign her name on checks and her new skill has assisted her with accounting tasks at the co-op.

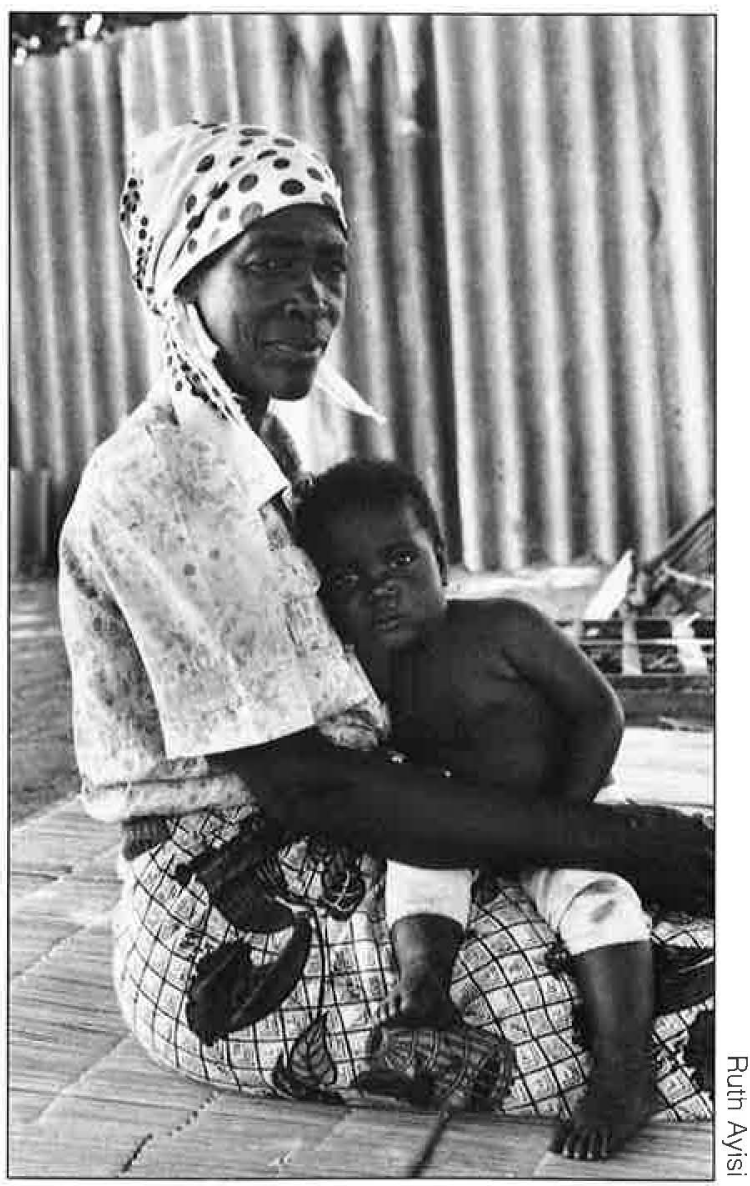


Yet, despite joining the co-op, for a long time Ms. Malecko still feared for her life. "During the war we suffered a lot," she said. "I was kidnapped with my brother and nephew three times, but we managed to flee each time. We were unable to sleep inside our homes at night. After 3:00 pm I would have to leave my home, and at night I would sleep in the bush.

"My life these days is much better. I sleep at home, I can buy soap, new capalanas (cloth wrappers), and I can save some money aside for the hospital in case l'm sick, although my health is better now. My only plan is to save money to construct a better house. My house now is only made of cane and is too small."

The new Green Zone initiative was developed in response to the government's decision to provide greater support to small production units in order to meet the critical need for food in the cities. From the start, however, it was stressed that the project would take a "self-help approach" that would "encourage cooperative workers to regard the results as a fruit of their own work rather than a free gift".

Much of the inspiration for the Green Zones approach comes from an Italian priest, Father Prosperino Gallipoli, who has lived and worked among the peasant farmers of Mozambique since the 1950s. The priest is a modest man, reluctant to talk about his important part in the success of the Green Zones project. But his vision was to create an organization that would empower people to take charge of their own lives-"people's development," he calls it. Therefore, one of his main roles has been to secure the kind of support, from the government and donors alike, that makes such autonomy possible. To do this, he has often had to challenge both the authorities and the "educated elite." However, his faith in the ability of peasant farmers to operate new technologies and ultimately to improve their social and economic status has remained firm. His valuable contribution is now widely recognized; UNICEF, for example, pays him a modest salary and he currently serves as a consultant manager to the General Union of Cooperatives (GUC).

\section{The General Union of Cooperatives}

The GUC was established in 1983 to better serve the needs of the cooperatives operating within the Green Zones. Although it was not intended to be a "women's" organization, it has become a strong one, with women regularly holding most, if not all, of the leadership positions: the current president, Selina Cossa, is a woman. At times, its independence has brought it into conflict with the Ministry of Agriculture, the ruling party, and even the national women's organization, but it has not only persevered, it has thrived. ${ }^{2}$

All individual co-op members automatically belong to the GUC, and membership is free. By 1985, the GUC had united more than 12,000 members and was unable to accept more. However, many of the women had joined solely because membership allowed them access to food and other commodities that were in scarce supply during the height of the war years. When economic structural adjustment policies were introduced in 1987 , and price controls removed, food became more readily available in the marketplace. Membership in the GUC then dropped by almost 50 percent, as those not really committed to the cooperative movement dropped out.

Today there are about 5,400 GUC members (approximately 95 percent of the women), grouped in approximately 182 coops located on 700 hectares of land on the outskirts of Maputo. All of the cooperatives, except one, are headed by women. The cooperatives vary in size, but average about fifty members each. Each individual co-op determines when and if new members are admitted, but given that the average size of available plots shared by members is around 3.3 hectares, in most cases too large a membership would be uneconomical.

In 1990, the GUC was registered as a company and the individual co-ops became its shareholders, constituting its General Assembly, which meets annually. Elections take place every three years by secret ballot. The GUC has a central office responsible for all juridical and administrative matters, accounts, and technical assistance for agricultural production. It is staffed by Green Zone cooperative members, who receive their salary from their own co-op. The staff is super- 
vised by a president, vice-president, and director, all of whom are elected by co-op members.

The GUC is run as a private enterprise. It has no institutional relationship to the Ministry of Agriculture, although it respects MOA policies, nor does it have any official relationship with the government or any $\mathrm{NGO}$

\section{How the Individual Cooperatives Function}

Most cooperatives have a democratically elected president, with different members responsible for agricultural production, marketing, social affairs, and accounting. All those in charge are elected by the cooperative members for a three-year period. Literacy and numeracy skills are not required to serve as an officer in an individual cooperative (to serve within the GUC it is necessary to be able to read and write). Within each cooperative, members hold regular meetings where they discuss the current level of wages, credit repayment, and the structure of the co-op. "The members are enthusiastic about the meetings," said one of the women. "We have regular attendance, and people are no longer shy to participate. We send our proposals to the General Union, which weighs the advantages and disadvantages of what we suggest." Typically the proposals the co-ops submit are for building new installations (such as setting up a mill to grind maize) or starting new projects (such as raising pigs)

Cooperative members pay themselves a regular salary, which is just above the country's minimum wage. This basic amount can increase if profits permit: usually about 50 percent of earnings go to pay back loans from the GUC; the other 50 percent is distributed among the members. These loans are primarily to purchase equipment that the GUC has been able to buy at wholesale cost. To secure loans from the GUC, a co-op must sign an agreement to pay back the loan within a certain period of time. The rate of interest charged is lower than the commercial rate. The main advantage of the system, however, is that the women get access to credit, which would be impossible for them to obtain from a commercial bank

Most co-op members live with their families near the plots of land they farm for the cooperative. Some have always lived there;

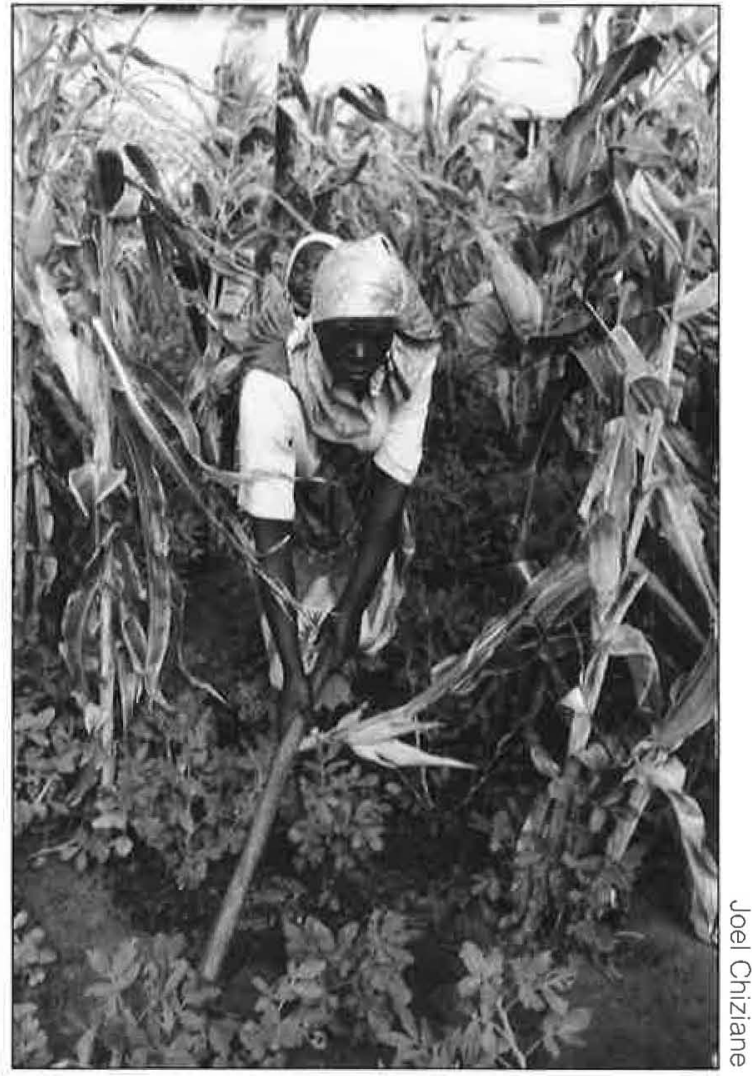

others have returned following the peace settlement. Some hold title to their land, but this is not a requirement for co-op membership. The GUC has been able to help many of the women who want private plots to secure the title to their land from the local authorities, although the process can be long and tedious. Today, almost all of the arable land around Maputo has been claimed, which restricts the further growth of the movement in the area.

\section{The Role of the GUC}

The members of the individual co-ops relate to the GUC either directly or through local unions. Local unions represent ten to fifteen cooperatives in the same area and form the middle level of a pyramid structure that includes the individual co-ops at the bottom and the GUC at the top. The aim, however, is for the co-ops themselves to become more self-sufficient and to rely less and less on direction from the GUC.

Probably the most critical role of the GUC is marketing the produce grown by the cooperatives. As the co-ops are located 
about 20 kilometers outside the city and most members have no access to private transport, the GUC buys livestock and produce from the cooperatives for sale in the city. The GUC maintains its own cashier so that the women are reimbursed immediately for their goods, thus eliminating the need for them to deal with intermediaries, such as banks. "Farm women are often timid about going into big banks," said one co-op member. "They would probably get robbed. They're not used to dealing with big quantities of money."

Because most co-ops are too poor to afford even the most basic equipment, the GUC also supplies basic farm implements and a range of other goods and services. For example, it has set up two storehouses which supply seeds, fertilizers, hoes, watering cans, hose pipes, construction material, diesel pumps, and the like. Because most co-ops cannot afford the market price of basic equipment, the GUC buys farm implements in bulk, at a discount, and then sells the items at cost to the co-ops. The members can pay for the items they take on credit. The GUC also conducts workshops to teach members how to assemble and repair their equipment.

In 1991, during a meeting of the General Assembly, 145 out of the existing 182 cooperatives opted for distribution of some property and means of production among individual co-op members, while still maintaining the cooperative structure. In 145 co-ops, then, land has now been distributed among the members. Low-cost farming instruments (such as hoes, watering cans, etc.) also have become individual property, while more costly infrastructure items-such as poultry units, vehicles, and water pumps - continue to be collective property.

Each year the GUC organizes teams of its own members to assist in evaluating activities and drawing up plans for the coming year. Regular meetings between the cooperative members in each area are also organized, offering the women an opportunity to exchange experiences and discuss problems with members of other groups. The GUC also assists members in solving conflicts, particularly over land "ownership," (usually between private farmers and some private companies) as well as helping them solve internal conflicts such as theft or when someone within the group usurps decision making authority without the consent of the rest of the members.

\section{Agricultural Production}

Today, chicken breeding is the cooperatives' greatest source of income; they currently supply 60 percent of the chicken for the Maputo market. Originally the co-ops had focused on raising pigs, but they proved too difficult to care for because there was not sufficient expertise available locally in terms of how to feed and care for them. The GUC was able to provide the cooperatives not only with baby chicks but with the necessary feed, vaccinations and technical back-up needed to raise chickens as well as providing help with transportation - all on a credit basis. In addition, there is a great demand for chicken in Maputo. The GUC has also been able to secure bank loans for individual groups to enable them to build poultry units and other infrastructure items.

The GUC buys all the chickens for resale to city markets, serves as a quality control check before resale, and assists the co-ops in maintaining their accounts. It has also constructed a modern slaughterhouse with deepfreezers to preserve chickens for sale to hotels, restaurants, and other establishments which buy in bulk. In 1993, besides supplying themselves (i.e., the co-op members), the GUC sold 822,000 chickens. Other crops, such as fruits and vegetables, have been less successful lately, due to the drought and, more recently, to plagues of insects which destroyed most produce. (While the co-ops have access to pesticides this does not protect them from certain types of plagues.) Yet, despite these setbacks, the co-ops managed to produce 3,500 tons of vegetables, 1,900 tons of cereal, and 400 tons of fruit in 1993.

Ms. Rosa is the mother of seven children. Her first husband was killed in the war. Today, Ms. Rosa sometimes earns more than her second husband, who is a printer. "My husband has no problem that I sometimes earn more than he does," Ms. Rosa said. "We have a lot of children, so although I earn more than most people, it's still not enough with these high prices of today."

The main activity of her co-op is chicken farming. Every forty-five days the women sell 12,000 chickens to the GUC. Members can buy chickens themselves at the subsidized price of 8,000 meticais (mt) - approximately U.S. \$1.30. 


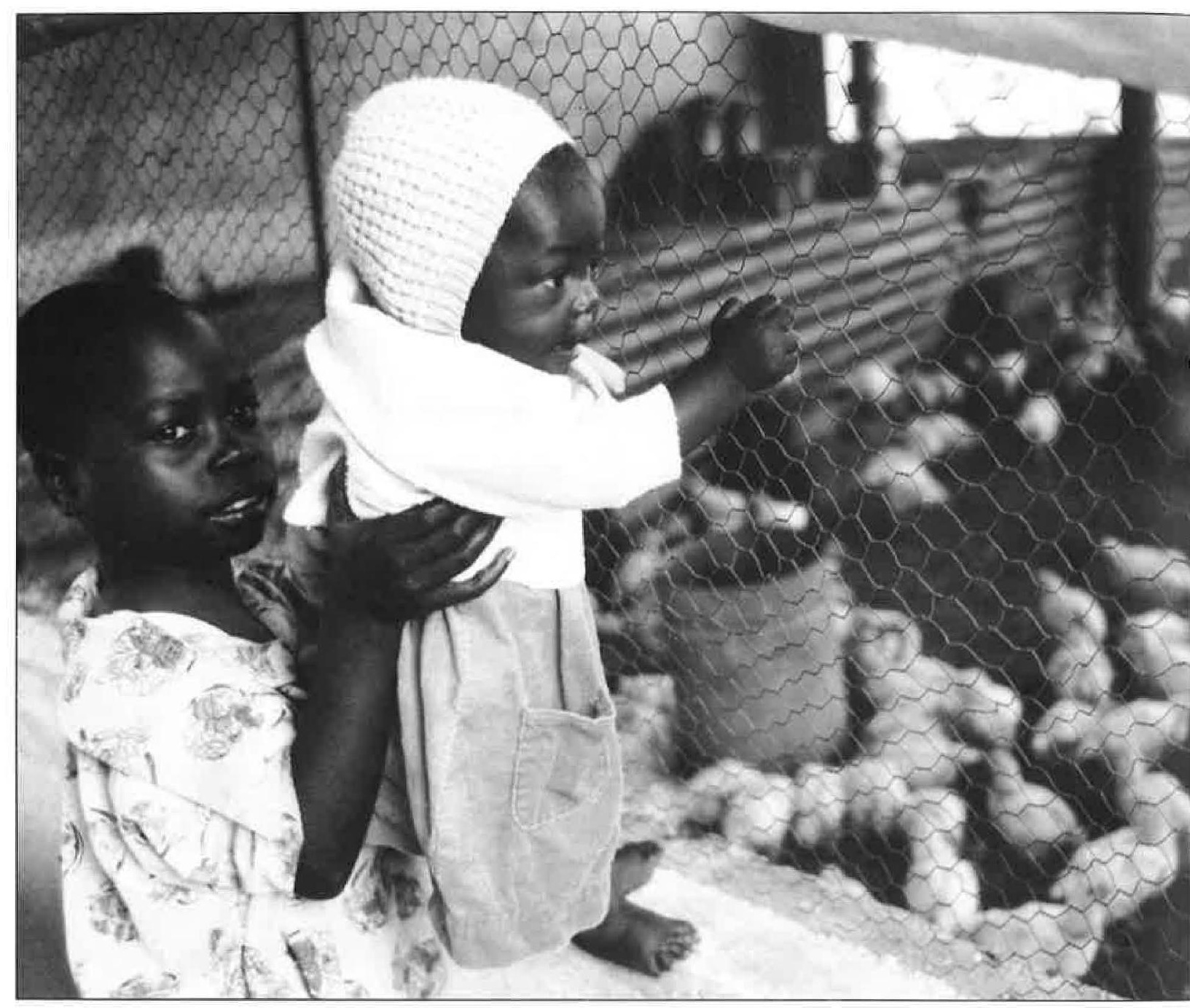




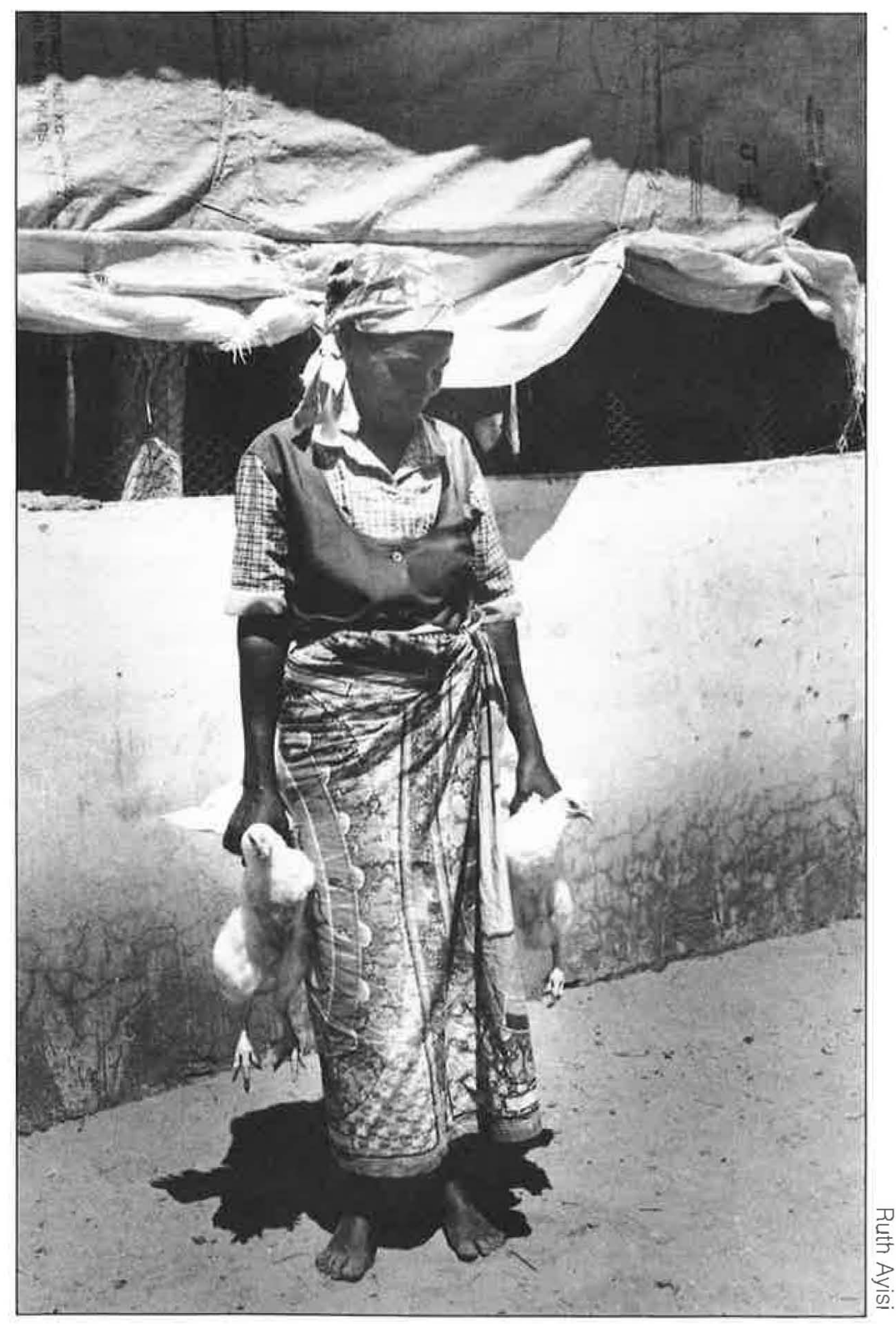


The market price is 25,000 $\mathrm{mt}$ (more than U.S. $\$ 4.00)$ per chicken. The previous month, her local union made 39 million mt (approximately U.S. $\$ 6,000)$ from selling chickens.

The bumper sales should enable the women to increase their monthly salary. While members' salaries vary slightly, all earn more than the minimum wage of 75,000 mt. Ms. Rosa earns, on average, 121,000 mt.

Ms. Rosa is more formally educated than the others in her group. Speaking in Mozambique's official language, Portuguese, she stresses how important but hard it is for women to obtain formal education. She, herself, managed to attend school up to the fourth grade. "But then my father stopped me from continuing because he said I would get into trouble with boys. He wanted me to get a job. I worked in a factory making exercise books until I was sacked for being too young. Then I helped a dressmaker. But I had wanted to continue to study."

Today all of Ms. Rosa's children who are old enough attend school.

\section{Training and Education of Cooperative Members}

Training has been an important component in ensuring the development of the co-op movement-particularly leadership training. The GUC maintains its own training center and all members attend a leadership training class for one week every year: ${ }^{3}$ In addition, over the past three years, the GUC has trained $900 \mathrm{co}-$ op members to serve as managers. To participate in the management training program, members must be able to read and write and have attended at least four years of school. Regular meetings with the GUC also help each co-op to develop budgetary plans. Most of the women have not had to deal with credit repayment before. Through this process, they are learning to look more towards the future, rather than just at immediate gains. Training has also been offered in subjects as varied as chicken breeding, agriculture, accounting, and pottery.

\section{More Than Just Farming}

As has been documented in a previous edition of SEEDS (Child Care: Meeting the Needs of Working Mothers and Their Children
No. 13, 1991), one of working women's primary concerns is who will care for their children while they work. With donor support, the GUC has been able to set up thirty-five day-nurseries. The nurseries, however, ran into difficulties when NGO support terminated. Lack of parental involvement and nonpayment of fees threatened continuation of these services, but the situation is gradually being resolved by the members themselves. The GUC has provided assistance in the construction of creches and has encouraged the co-ops to pay staff out of their profits.

Older children usually attend government primary and secondary schools. However, the GUC did build one secondary school in 1986 which is now attended by 1,000 students. A commercial institute has also been established which offers training to older children in economics and accounting. It is hoped these young people will, in turn, be able to assist their mothers in the running of the cooperatives. Enrollment has already increased from 14, when the institute opened, to 40 students who study in the evenings.

\section{Funding and Support}

To be able to offer such wide-ranging support, the GUC has had to rely on the financial support of international and non-governmental organizations. To date, the GUC has received assistance from the governments of Norway, Switzerland, and Canada; private organizations such as the National Council of Negro Women in the United States; and UNICEF. Gradually, however, it is building a foundation for financial self-sufficiency, and since 1992, the GUC has received only occasional outside aid. Its chicken-breeding project, supported by a World Bank Ioan and credit from local banks, is currently a major source of income. With the GUC standing as collateral, the co-ops are able to obtain commercial loans through regular channels without any support from the government.

As one donor report recently stated: "The GUC has developed from a couple of illiterate women into a powerful peasant organization." At the national level, the GUC has also become active in the formation of the National Union of Peasants (UNAC). Today, the UNAC is probably the NGO most representative of rural women in Mozambique. 


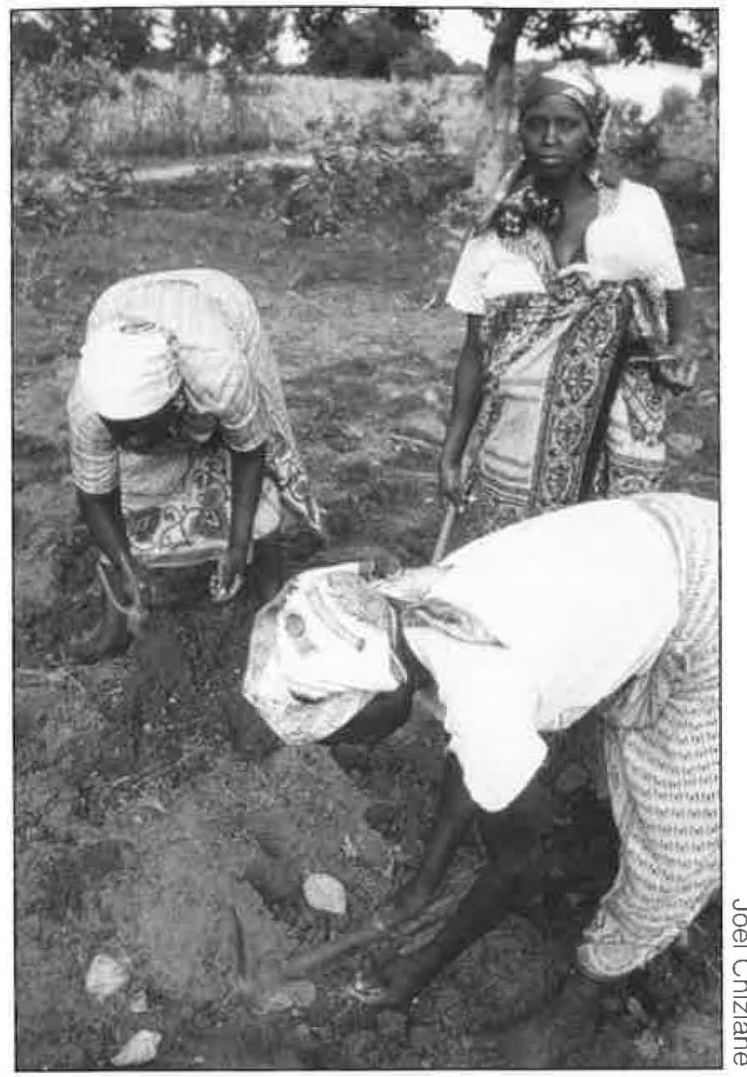

\section{People's Development Is More Than Economic Development Alone}

Economic power, personal development, and choice are probably the main benefits enjoyed by the women of the Green Zones, many of whom are widowed or divorced. "Women don't have to put up with bad treatment anymore," says the forty-yearold president of a group of five cooperatives in Tsalala zone. "They are earning money, some for the first time. They can survive by themselves."

Without the Green Zones initiative, most of the women-who have little, if any, formal education-would be either desperately poor, or trapped in unhappy marriages. While the co-ops cannot provide answers to all their problems, the women have been given a chance to earn a wage. Thus they are able to support their families, improve their skills, and contribute to the local economy.

At first, many of the married women found that their husbands were threatened by the Green Zones initiative. In the early days, men often beat up their wives or even divorced them if they joined. But gradually, as the women began to earn money, their husbands became more accepting. A few men even joined, but generally they serve as guards or "handy men."

Louise Fomo is president of the 29th of September co-op. A mother of three children, Ms Fomo chose to find another husband three years after her first spouse died. "It was my wish because I was young when my husband died and I needed support. I had serious problems. I had nobody to help me. I had to beg my kin for food."

Ms. Fomo is the second wife of her new husband. Asked whether she minds the fact that her husband has another wife, she replies, "I don't want to lie and say it's easy. But I have been a second wife before, so it is not a new thing for me. I have my own house and I have nothing to do with the first wife." And with the help of the Green Zones, which she joined ten years ago, Ms. Fomo has managed to build up a life of her own against major odds.

The war forced her to abandon her own machamba. At that time, even the co-op was unsafe. Everybody had to leave by 2:00 pm to take refuge in shelters made of plastic sheeting and sticks they had built around the city. Families in her area were often kidnapped, and the co-op itself was attacked and chickens stolen. Having to leave the co-op early also disrupted her literacy classes. Ms. Fomo, who does not know her age, has had no formal education and cannot read or write.

Even though there is now peace, Ms. Fomo still cannot work on her own plot because it is far from her home and public transport is costly. Furthermore, much of the land that was deserted during the war years was mined, as many people, particularly women and children, have found out.

\section{Looking to the Future}

Most co-op members are now keen to invest their profits for the future. Many of the women talk about investment plans for the co-ops if they have extra cash, rather than the immediate satisfaction of a wage increase. For example, members talk about buying a mill, so that they do not have to send 
their maize away to be ground, and about building pens to keep pigs and hutches for rabbits.

\section{A Difficult Act to Follow}

The Maputo Green Zones is a success story which, thus far, has proved difficult to repeat in other parts of Mozambique. After supporting the Maputo Green Zones since 1984, UNICEF is currently directing most of its attention to the Green Zones of Beira, Mozambique's second largest city and major port. However, while the goal of the project is the same - to help women develop economically and personally - the economic activities in Beira are less geared towards agriculture. The experience in Beira thus far clearly demonstrates why trying to replicate "model" projects in other settings is often problematic.

For example, despite the existence of a local Green Zones office, the women who farm in the Beira Green Zones are very scattered and their plots are much smaller, and nearer to the city, than those in Maputo. Also, unlike Maputo, there is no existing cooperative structure on which to build. More importantly, like the other major cities in Mozambique, Beira is not nearly as large a market for produce as is the capital, Maputo. Nor does Beira possess the infrastructure, capital, or business expertise that contributed to the success of the Maputo project. The UNICEF project in Beira has, therefore, had to bring the women farmers together as individuals, helping them attain skills primarily in horticulture and non-farm-related sectors rather than being able to develop or work through a farm-based structure.

\section{The Beira Green Zones Project}

The women in this project differ from those in Maputo in that they are caught in a trap of being unable to fully exploit agricultural activities because of insufficient land, while also being unable to break into the formal employment sector because of lack of education. Typically, these women are subsistence farmers who grow one or two crops, usually rice and sweet potatoes; but last year, a plague of grasshoppers destroyed the entire rice crop. Other women in the area are now without any land because they had to flee during the war, leaving behind their plots, tools, and possessions. Many try to earn money by working on other people's farms or by brewing beer.

The Beira Green Zones project was actually established some years ago, but membership dwindled over the years due to the war when many women had to abandon their land and move into the city. Now it is growing once again. Over 300 women in three of Beira's poorest suburbs currently benefit from the project. There is no direct relationship between the Maputo and Beira projects: the former operates through the GUC while the latter is linked to the Ministry of Agriculture.

The Beira project is a center-based program. The centers are open in the afternoon to allow the women time in the morning to tackle their daily chores, fetching water and firewood, working on their machambas, doing their washing, and preparing meals. Activities focus on practical concerns such as horticulture and constructing improved stoves. At a demonstration of how to construct new cook stoves, a woman stamped energetically on a mixture of sand, water, and grass, while another mixed up the clay with her hands. They then placed the mixture in a mold and carried it into a shed. With good maintenance these stoves, which are safe and use little fuel, can last up to three years.

As in the Maputo project, literacy training is an important service provided at the centers. Unlike in some other parts of Mozambique, most men in Beira appear keen to have their wives learn to read and write. In fact, many women say it was their husbands who encouraged them to join the classes. It probably helps that the centers have been existence for six years and the leaders are respected members of the community.

Especially relevant to the women farmers are the horticultural classes offered free of charge. A local extension worker gives classes once a week to improve the traditional agricultural practices used by the women. Two centers have actually set up demonstration plots for experimental purposes. The project also sells vegetable seeds to the women at subsidized prices. 


\section{Organization and Management}

Given the project's limited resources, activities are now limited to three centers. Initially the project was coordinated by the Beira Green Zones office, a division of the Provincial Directorate of Agriculture, but now the women themselves are in control. Each center is run by a board made up of three women elected by the members. They manage a budget of ten million meticais (approximately U.S. $\$ 1500$ at the current exchange rate) provided by UNICEF and meet weekly to discuss center activities. Any problems or suggestions for change are then put forward at a monthly meeting which is attended by a UNICEF representative and someone from the Beira Green Zones office. All decisions are made by concensus. Because the women lack management experience, a coordinating team made up of an extension worker, an accountant, and a literacy teacher from the Green Zones office assist in the management of each center.

In March 1993, the members of the centers and the coordinating team carried out a survey to assess the women's needs and expectations. The survey indicated that the following areas should be developed:

- Raising funds, mainly by selling coal and firewood and by setting up and offering the services of a diesel-operated grinding mill. The income earned will be shared among the women and used to cover the cost of running the centers;

- Training in literacy and adult education, sewing, food processing, cooking, horticulture, making improved stoves, and provision of credit;

- Promoting the centers and mobilizing more women to join because they are now operating at less than capacity and would like to serve more poor women farmers in the suburban area.

"One of the major challenges now is reaching the women," says Adelaide Alfiu, the extension worker. Ms. Alfiu and her two colleagues at the Green Zones office usually go to the fields themselves to ask women farmers to come to the centers. Sometimes women hear about the projects and come on their own accord, like Rosita Salimo.

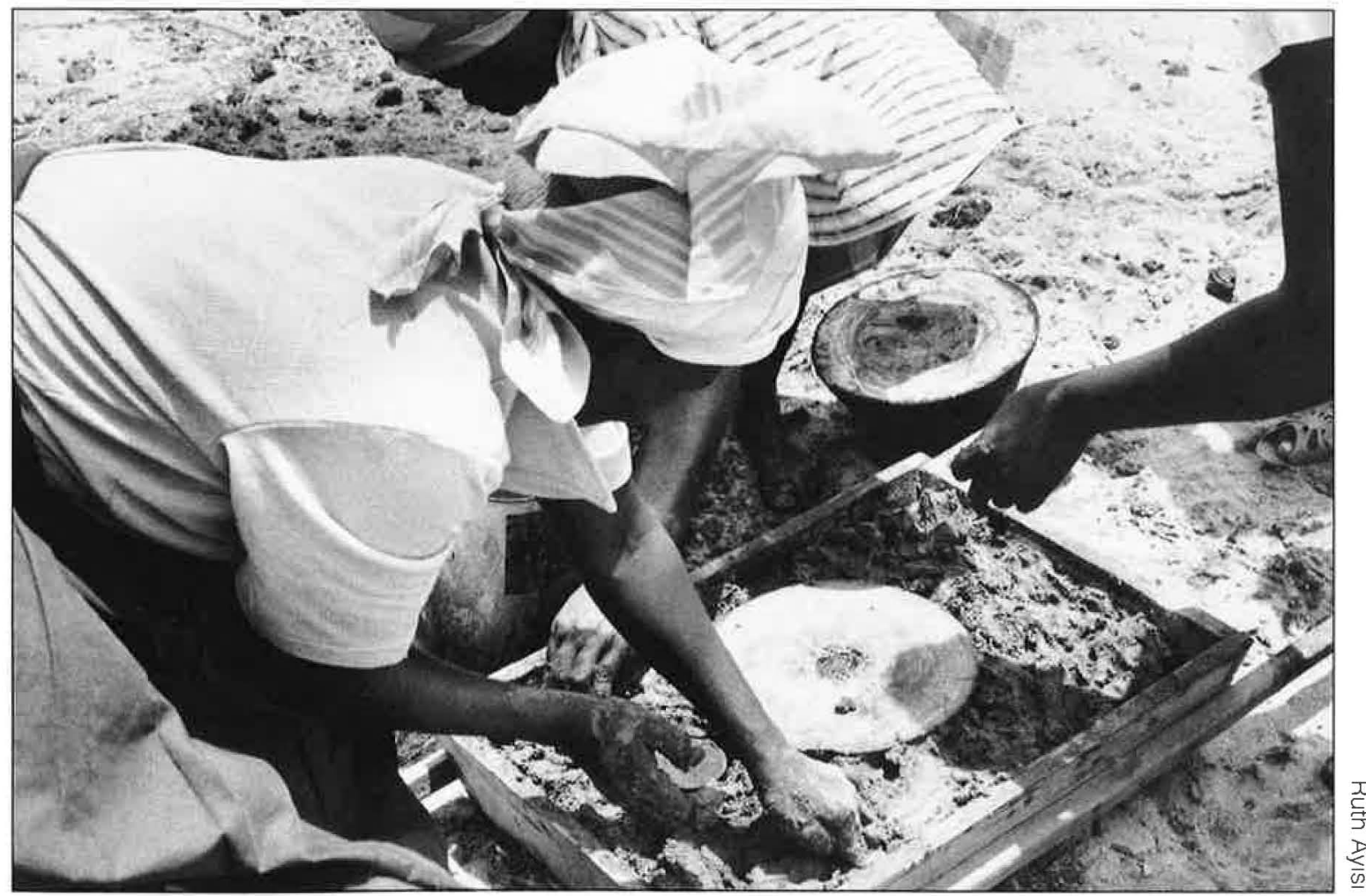




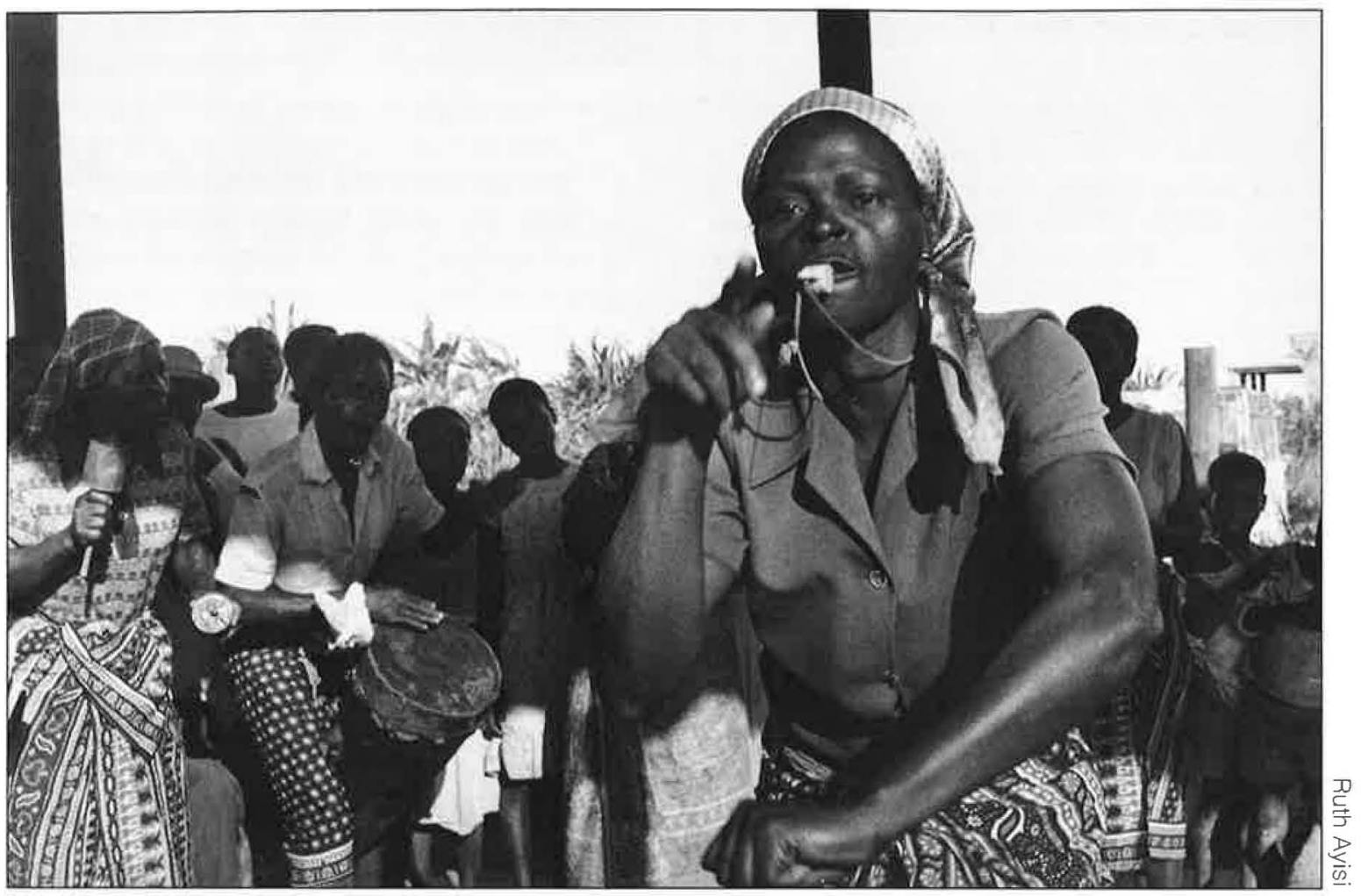

Rosita Salimo first came to the "Centro De Vaz, " one of the three training centers, as a last resort. Her radiant yellow cloth, wrapped around her tiny waist, and matching blouse contrast sharply with her cracked skin and broken toenails. She enters the classroom hesitantly and begins to tell her story in the local language, Masena.

"I came to Beira two years ago with my husband, who worked as a plumber, but he is now unable to work after becoming mentally ill," says Ms. Salimo, the mother of five children, four of whom are under thirteen years of age. She has a small plot of land where she grows rice, but only for the family's consumption. During the planting and harvesting season, she sometimes has the opportunity to work on other people's farms for about 5,000 meticais a day (U.S. \$1).

"I can't buy enough food for my family," she says. "I can bear the hunger, but the children can't." None of her children go to school because Ms. Salimo has no money for school books or other basic items; each child has only one item of clothing. Ms. Salimo has her yellow capalana, or wrap, for special occasions; otherwise she just has one other cloth which she uses for farming. "Sometimes I can buy soap," she added, "but I prefer to buy food."

Yet Ms. Salimo feels hopeful that participating in the center can help lift her out of the extreme poverty engulfing her. Before she became involved, she had heard people in her community talking about the center and its activities. As Ms. Salimo talks about her wish to participate, music can be heard. She walks out to see what is going on.

Standing in a circle, a woman blows a horn, a man drums, and a group of women clap a rhythm with blocks of wood. Others use whistles, and the rest, including some children, clap in perfect time. The women take turns entering the center of the circle, dancing barefoot to the thumping beat.

Suddenly MS. Salimo is no longer a newcomer. Her head held high, she dances into the middle of the circle by herself, moving every part of her body, completely lost in the music, already seeming to leave her problems behind.

Of course, like that of the other women, her poverty is not going to vanish, but Ms. Salimo now has the chance to gain skills that can help her to earn more money, to learn to read and write, and, at least for a while, to forget her problems and dance. 


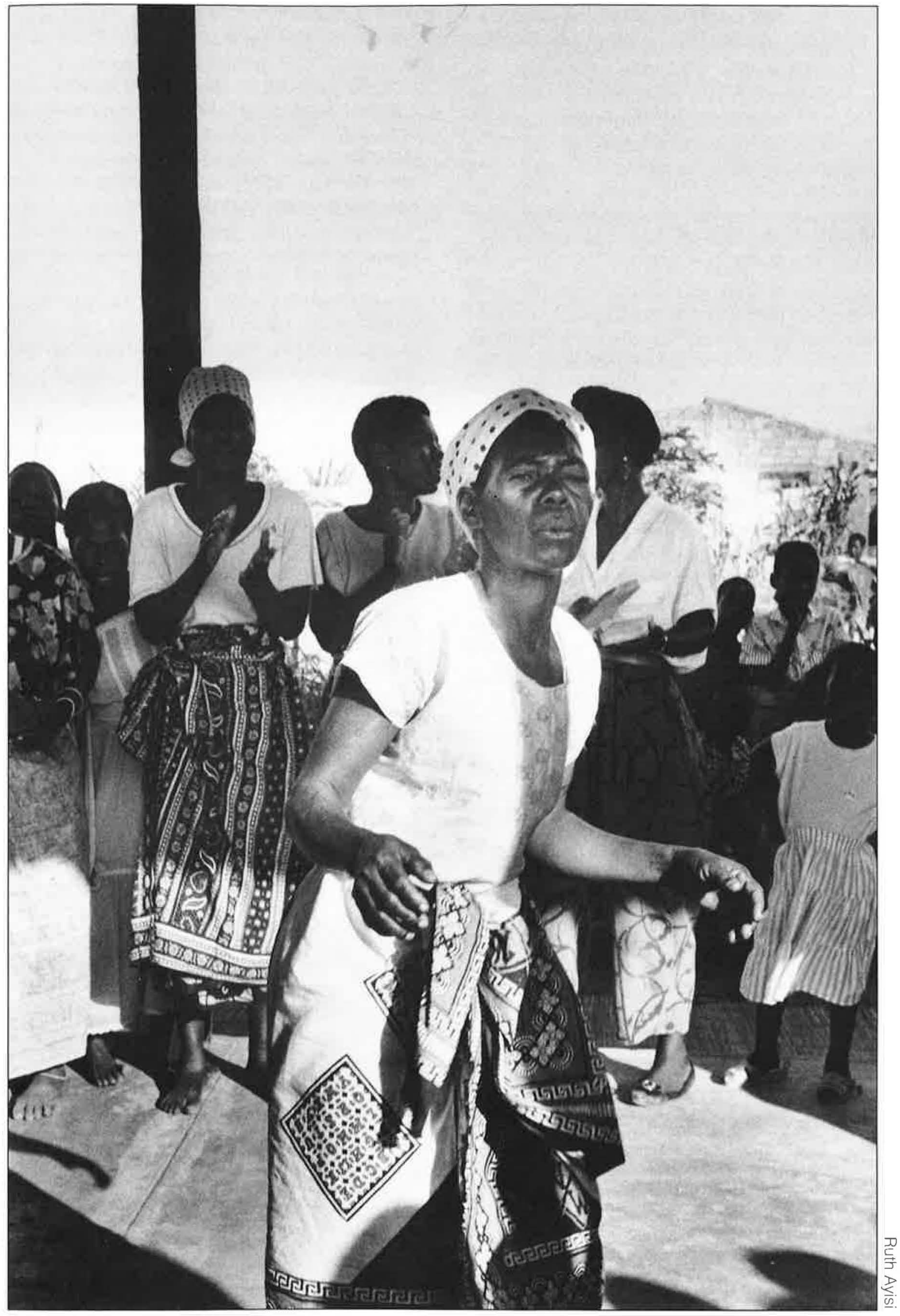




\section{Credit Opens Doors}

Because agricultural production is not organized the way it is in Maputo, most of the women farmers who participate in the Beira program need other, non-farm-based opportunities to earn cash income. In July 1993, ten women from each center participated in a two-week course run by the literacy teacher on how to carry out a feasibility study and manage money. A cash credit of 200,000 meticais (about U.S. \$31) was given to each participant who qualified according to the terms laid down by the group (e.g., proven commitment to the group, completion of training program, up-to-date vaccination card for her children) to develop or expand a small business. Funding was provided by UNICEF.

Most of the women used the money to invest in activities related to their farming activities, such as the sale of home-brewed beer or the resale of vegetables and maize flour in the local community. Others became engaged in the resale of dried shrimp and fish in towns and villages located further inland. With the money they have earned, these women have been able to improve their diet and buy clothes, school books, and pens for their children, as well as putting aside a small portion as savings. The women pay 3 percent interest on their loans, and so far there have been no delays in repayment.

At the end of the training course, the women performed a humorous play about the pros and cons of business life in an unpredictable market. The play will be used in the next course to provoke discussions and draw attention to marketing problems.

Emilita Antonia was one of the beneficiaries of the first course. A thirty-three-year-old mother of six, Ms. Antonia runs her household pretty much by herself. Her husband has been away for years, working in South Africa. "The previous year he sent money to us, but this year he hasn't sent anything," says Ms. Antonia.

Despite being, in effect, a single parent and only having passed grade one at school, Ms. Antonia has managed to establish a small business. She was one of those who received credit of 200,000 meticais, which she used to buy wholesale bags of maize, bananas, and oranges, which she then resells. Last month she made a profit of 50,000 meticais (approximately U.S. \$8).

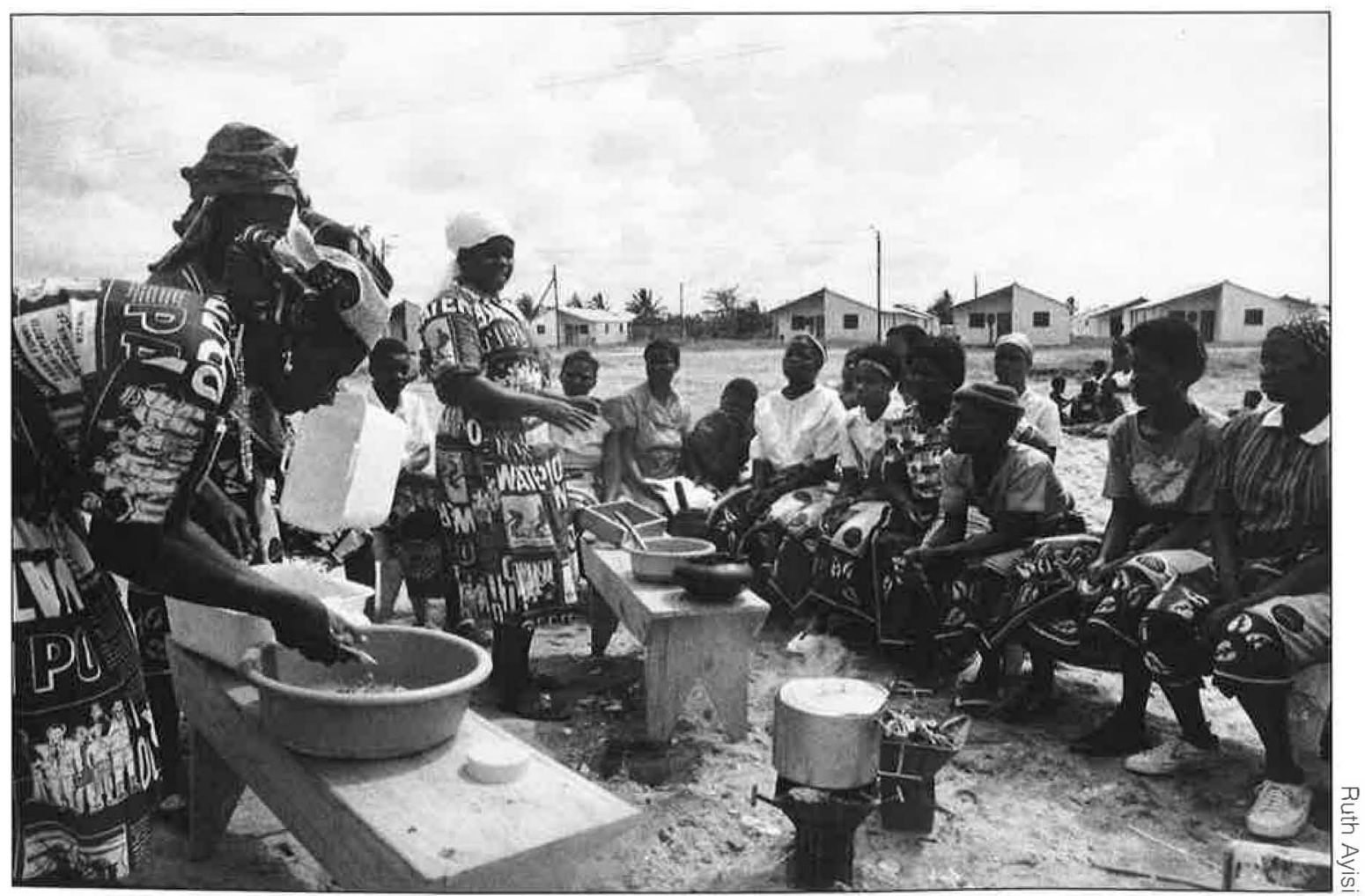




\section{Lessons Learned}

1. Exporting development models, even within the same country, is a challenge which requires attention to the unique circumstances in each locale. In many developing countries, business, government, and development assistance are all centered in one major city. Thus, as is the case in Mozambique, what worked in the capital, Maputo, could not be readily transferred to another urban site-even the secondlargest city. In Maputo, the UNICEF project was able to build upon an existing cooperative structure put in place to help meet the food needs of the capital city. This infrastructure is lacking in Beira, which has resulted in development of a more traditional intervention that is thus having, at this early stage in its development, less direct impact on women's economic productivity.

2. People need to see how they will benefit and know they have some degree of control before they can be brought together to work productively. Mozambicans did not naturally warm to the idea of joining cooperatives, based on their past exploitation, first by the Portuguese (who forced thousands of people to toil on large estates as virtual slaves), and then by a number of unsuccessful policies of the socialist government aimed at the collectivization of agriculture. To bring farmers together into a cooperative structure, it was necessary to demonstrate the economic advantage that they themselves would gain and to give them an active voice in operating and guiding the cooperative structure.

3. It is important that projects be realistic about the degree of commitment that can be expected from participants and their motivation for joining a specific project. Many women initially joined the GUC because it offered access to goods and services that were in short supply or far too costly during the height of the war years, rather than because they were committed to the cooperative movement. Fortunately, the majority of women realized the value of working together and remained involved even when market controls were lifted and goods became more readily available.

4. The marketing role of the GUC has been pivotal in ensuring the cooperative members an outlet for their produce. By providing slaughterhouse facilities, cold storage, and contracts with merchants and retailers, the GUC has been able to provide a stable market for the women producers. They have removed the need to deal with middlepersons and are giving the women farmers immediate access to their profits, without the need for them to deal with banks.

5. It is important to view mainstreaming as more than providing opportunities to earn. It is important for women to secure assets in their own right. The GUC has also been instrumental in assisting many of the women to gain title to their land. The importance of ownership is further underscored by the decision of many of the cooperatives to make some low-cost farming equipment private property. Thus, the women are seeking to find the right balance between private and collective ownership that best serves their needs.

6. The experience of the Green Zones projects emphasizes why women's economic needs can rarely be addressed in isolation. Even though the women farmers in Mozambique were desperately poor, economic objectives were not their only concern. Over and over again, the women mention the value they place on literacy classes in a country that has one of the highest levels of illiteracy in the world. Offering women literacy classes and management training, helping them to reduce their heavy workloads by providing access to water, child care, and health facilities, as well as offering children a place in school, are all vital elements in the success of the Maputo Green Zones project.

7. The Green Zones projects have also been instrumental in empowering women to make choices in their personal lives, in some cases offering them an alternative to abusive marriages and in others helping them to gain greater respect and autonomy within their homes. The ability to earn income, combined with the supportive structure of the cooperatives, has been the key.

8. There is power in numbers. The GUC, in addition to supporting the cooperatives, has become influential within larger forums that affect the well-being of poor women in Mozambique. Thus, the GUC is able to provide representation for its members within the broader political arena. 


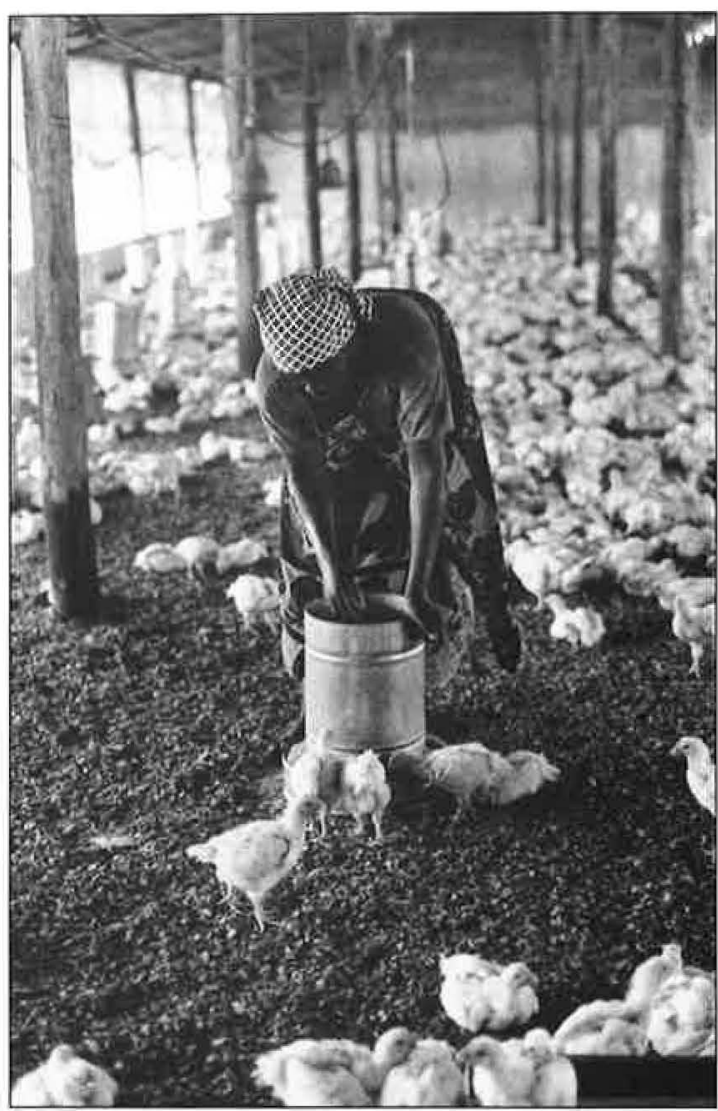

is $\quad$ E.

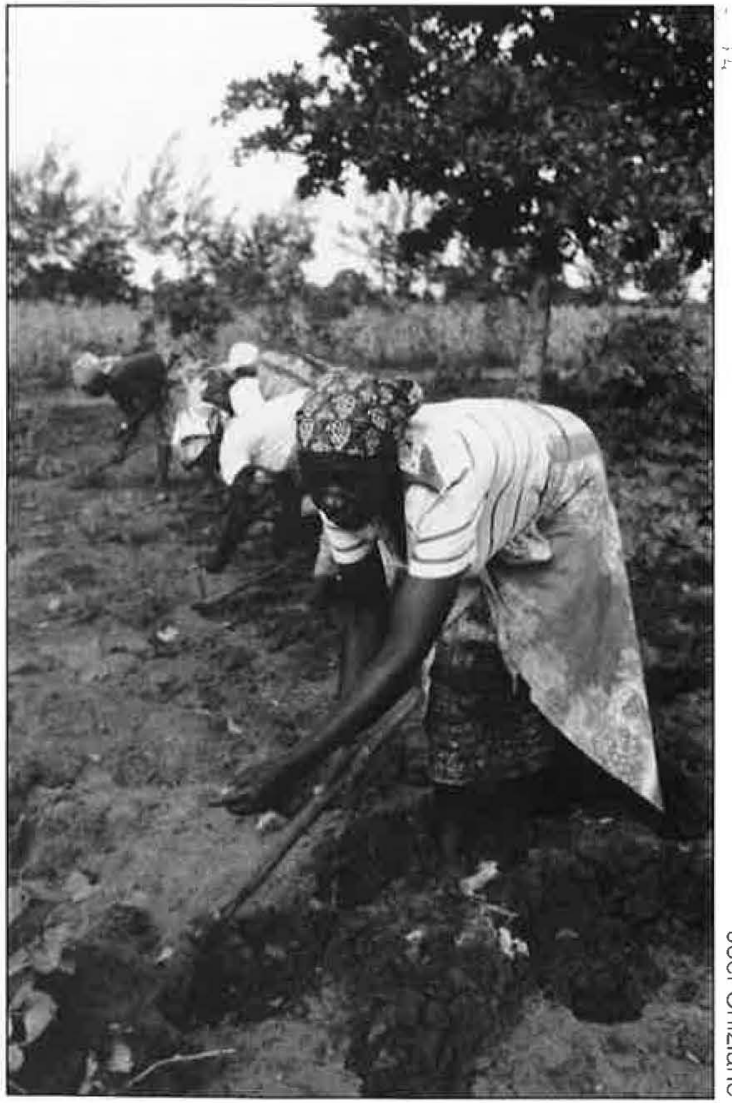

\section{涩 $\stackrel{D}{\leq}$}

$\therefore$, it

\section{Notes}

1. Irene Fehr, 1985, "Women in Agricultural Cooperatives: Green Zones Maputo" (Presentation at the Workshop on Exploring Alternative Programs for Women, Comilla, Bangladesh, February 1985). UNICEF (undated) "Mozambique's Green Zones Cooperatives - A Challenge" (project documentation). Nadja Youssef, 1985 , Trip report of visit to the Mozambique Green Zones (UNICEF, July 1985).

2. Stephanie Urdang, 1989, And They Still Dance: Women. War, and the Struggle for Change in Mozambique (New York: Monthly Review Press)

3. Kristin Helmore, 1989, "Grass-Roots Projects," special report of the Christian Science Monitor, March 1, 1989. 
Design: Ann Leonard

Cover Photo: Joel Chiziane

Typography: Line \& Tone Group, Inc.

Printing: Graphic Impressions

\section{Other Editions of SEEDS Currently Available}

No. 2 Hanover Street: An Experiment to Train Women in Welding and Carpentry-Jamaica (English, Spanish)

No. 3 Not Available

No. 4 Women and Handicrafts: Myth and Reality-International (English, Spanish, French)

No. 5 The Markala Cooperative: A New Approach to Traditional Economic Roles-Mali (English, French)

No. 6 The Working Women's Forum: Organizing for Credit and Change-India (English, French)

No. 7 Developing Non-Craft Employment for Women in Bangladesh (English)

No. $8 \mathrm{C}$

The

No. 9 ;

No. $1 \mathrm{C}$

the

No. 11

HQ

Ayisi, Ruth Ansah.

1870.9 Supporting women

No. 12

.543

farmers in the

no. 17

green zones of

Mozambique

No. 13

POPULATION COUNCIL LIBRARY

No. 14

NEW YORK

is

No. 15

No. 16

GAYLORD S

an

d

Id

rs

$f-$

$7 t$

of

If you would like additional copies of this issue or any of the editions of SEEDS listed above, please write to us at the address given below. Copies of selected SEEDS issues in local languages are currently being published by organizations in the following countries: Egypt, India, Indonesia, Kenya, Nepal, Pakistan, Thailand and Vietnam. Please write to us for more information if you are interested in these materials.

$$
\begin{gathered}
\text { Ann Leonard, Editor } \\
\text { SEEDS } \\
\text { P.O. Box } 3923
\end{gathered}
$$

Grand Central Station

New York, New York 10163, U.S.A. 


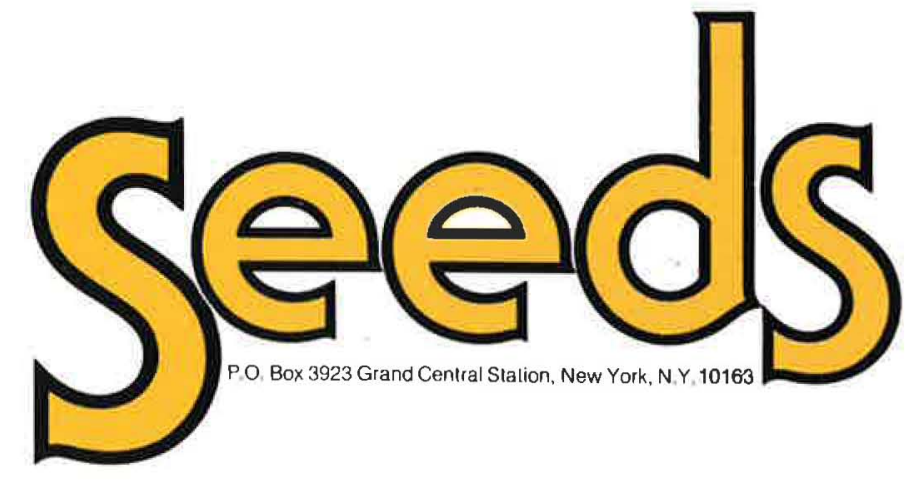

